\title{
Expression of Engineered Antibodies in Plants: A Possible Tool for Spiroplasma and Phytoplasma Disease Control
}

\author{
Y. D. Chen and T. A. Chen
}

Department of Plant Pathology, Rutgers University, New Brunswick, NJ 08903.

Accepted for publication 26 May 1998.

\begin{abstract}
Chen, Y. D., and Chen, T. A. 1998. Expression of engineered antibodies in plants: A possible tool for spiroplasma and phytoplasma disease control. Phytopathology 88:1367-1371.

In an attempt to develop maize plants with resistance to corn stunt spiroplasma (CSS), a single-chain Fv fragment (scFv) gene that was con-

expressed in a cell line of maize. However, plants regenerated from this transgenic cell line showed no distinct resistance to CSS infection under the greenhouse conditions. The affinity and functionality of $\mathrm{scFv}$ in vivo and the locations of CSS and expressed scFv in maize could be a part of the contributing factors affecting this result. Progress of expressing antibodies in plants for plant pathogen resistance is also discussed.
\end{abstract} structed from antibodies with strong inhibitory activity against CSS, was
Unlike vertebrate animals, plants do not have an immune system to make antibodies for identifying and inactivating invading pathogens and parasites. However, with the advent of genetic engineering and transgenic plant technology, plants can be transformed with antibody genes to produce functional antibodies or antibody fragments $(16,18,22,33)$. Tavladoraki et al. (37) and Voss et al. (41) reported that, by employing this technology, they were able to produce transgenic plants resistant to viral infections. This development may have opened a new avenue for plant biologists for rendering plants more resistant to pathogen attack. Expression of antibodies or antibody fragments that bind antigens essential for pathogenesis (such as toxins, enzymes, and movement proteins) in transgenic plants has been considered as an alternative approach for plant disease control.

Phytoplasmas and phytopathogenic spiroplasmas, which are wallless prokaryotes, cause more than 300 plant diseases worldwide. These diseases can dramatically affect the yield or may result in the total loss of a crop. The pathogens replicate in plant phloem and are transmitted in nature by phloem-feeding insects. To date, few effective control measures are available for these diseases. Since some antibodies against the class Mollicutes have the ability to inhibit their growth and metabolism in vitro $(14,24,39)$, these specific antibodies might inhibit growth of spiroplasmas (or phytoplasmas) in vivo if they were present in a plant and in sufficient quantities. In this paper, we will focus on our success in expressing an anti-corn stunt spiroplasma (CSS, Spiroplasma kunkelii) single-chain Fv fragment (scFv) in maize and on our attempts to develop CSS-resistant maize plants (11). In addition, we will address problems we have encountered. Hopefully, this may be helpful for other researchers employing this strategy for spiroplasma and phytoplasma disease control.

\section{ANTIBODIES AND ANTIBODY ENGINEERING}

Antibodies or immunoglobulins are a group of glycoproteins present in the blood serum and tissue fluids of mammals. All anti-

Corresponding author: T. A. Chen; E-mail address: chen_c@ aesop.rutgers.edu

Publication no. P-1998-1022-010

(C) 1998 The American Phytopathological Society bodies have a common structure consisting of two identical heavy (H) chain polypeptides and two identical light $(\mathrm{L})$ chain polypeptides held together by disulfide bridges and noncovalent bonds. Both light and heavy chains contain two different regions. Constant regions $\left(\mathrm{C}_{\mathrm{L}}\right.$ and $\left.\mathrm{C}_{\mathrm{H}}\right)$ have amino acid sequences that do not vary significantly between antibodies of the same subclass. The variable regions $\left(\mathrm{V}_{\mathrm{L}}\right.$ and $\left.\mathrm{V}_{\mathrm{H}}\right)$ from different antibodies do have different sequences. The variable regions are located at the aminoterminus of the antibody chains and form the antigen-binding sites. The variable regions consist of alternating framework (FW) and hypervariable, or complementarity-determining, regions (CDRs). The greatest sequence diversity occurs in the CDRs, which play a major role in determining antigenic affinity and specificity of an antibody. The FW region sequences are, however, more conserved.

For therapeutic applications, to eliminate the immune reactions against mouse antibodies, human monoclonal antibodies are desired. However, there is no general method to generate human monoclonal antibodies comparable to the approach of making mouse monoclonal antibodies. The lack of human monoclonal antibodies has stimulated the development of antibody engineering. By using genetic engineering methods, recombinant antibodies with a mouse variable region and human constant region (so-called chimeric antibodies) or with a mouse CDR and human FW and constant region (so-called humanized antibodies) have been constructed $(7,26)$. Furthermore, by bypassing conventional chemical coupling methods, a recombinant immunotoxin can be directly constructed by fusing a toxin gene to an antibody gene (8). The antibody part of an immunotoxin mediates selective binding, while the toxin portion is involved in the killing of target cells. The limiting step in rapidly constructing recombinant antibody molecules is the determination of the variable-region sequence. With the advent of polymerase chain reaction (PCR) technology, antibody genes can be directly isolated, because DNA sequences in the first FW and constant regions are relatively conserved for all classes of antibodies in a given animal. Genes for different antigenbinding proteins (such as full-size antibody, Fab, and scFv) can be constructed by mixing primers corresponding to different domains of the constant regions and primers in the $5^{\prime}$ leader sequences or FW 1 region in PCR reactions. The construction of $\mathrm{scFv}$, in which 
the variable domains of antibody heavy and light chains $\left(\mathrm{V}_{\mathrm{H}}\right.$ and $\mathrm{V}_{\mathrm{L}}$ ) are linked together by a short designed linker peptide, is one of the most valuable innovations in the area of antibody engineering $(6,25)$. The development of the phage display system has allowed antibody fragments ( $\mathrm{Fab}$ and $\mathrm{scFv}$ ) to be expressed on the surface of filamentous bacteriophages such as M13 or fd. Positive phages can be enriched through panning against antigens. Therefore, the screening of expressed antibodies for correct antigen binding from a big library is now relatively easy (13).

\section{EXPRESSION OF ANTIBODIES IN PLANTS}

Advances of gene manipulation techniques have opened up the possibility for creating new genetic properties in crops by genetically modifying them to express foreign genes. This advancement is not possible through traditional breeding programs. Since the first fertile transgenic dicots were produced in 1983 (4), genes that confer resistance to diseases, insects, and herbicides or that enhance nutrition have been transferred into a wide range of plants. Foreign genes can be introduced into plants by Agrobacteriummediated gene transfer or by direct gene transfer such as particle bombardment and electroporation.

It is also feasible to express both full-size antibodies and antibody fragments in plants. One successful approach to express fullsize antibodies in plants was developed by Hiatt and coworkers (22). The antibody heavy and light chain genes were first expressed separately in different plants. Plants expressing heavy or light chains were then crossed, and functional antibodies were produced in the progeny. In another approach, both genes were cloned into one expression cassette with either tandem or divergent promoters. After introducing this construct into plants, functional antibodies were detected $(18,40)$. For successful expression of full-size antibodies in plants, it is very important to include a signal peptide sequence in front of both heavy and light chain genes to ensure proper assembly in the endoplasmic reticulum (ER) $(22,23)$. Both murine and plant secretory signal peptides are well suited for this purpose $(5,18,22,40)$. Expression of functional full-size antibodies without signal peptides has not been achieved, probably because the reducing environment in the cytoplasm prevents disulfide bond formation. scFv lacking any signal sequence have been functionally expressed in the cytoplasm $(33,37)$. However, $\mathrm{N}$-terminal signal peptide and C-terminal KDEL sequences (a signal for retention in the ER) have been reported that increase $\mathrm{scFv}$ expression levels and their stability in plants $(2,21,34)$. Because of their relatively small sizes that facilitate good tissue penetration, no assembly requirement, and ease of construction, $\mathrm{scFv}$ genes are attractive candidates for plant transformation in studying plant physiological processes $(2,33)$ and disease resistance (37). Problems of expression of complete antibodies such as glycosylation and intermolecular disulfide bond formation can be circumvented through expression of scFv. The reader is directed to a more extensive review of expressed antibodies in plants (15).

\section{ANTIBODIES AGAINST PLANT PATHOGENS IN PLANTS}

When Hiatt et al. (22) first expressed functional antibodies in plants, they envisioned the application of plant-expressed antibodies in plant disease resistance. Tavladoraki et al. (37) succeeded in employing this strategy for disease control. They constructed a $\mathrm{scFv}$ from a monoclonal antibody that had high affinity for artichoke mottled crinkle virus coat protein. By expressing this $\mathrm{scFv}$ in tobacco, the transgenic plants showed a lower frequency of infection and slower development of disease symptoms. Voss et al. (41) cloned full-size cDNAs of heavy and light chains from a monoclonal antibody that had a high affinity towards epitopes present only on the surface of intact tobacco mosaic virions. By expressing heavy and light chains simultaneously in tobacco, functional antibodies were assembled. Upon viral infection, the transgenic plants showed a reduction in the number of necrotic lesions. The reduction is correlated with the amount of antibody produced in transgenic plants. In a recent study, Baum et al. (5) cloned the heavy and light chain genes from a monoclonal antibody specific to stylet secretions of the root-knot nematode and introduced them independently into tobacco. After crossing plants expressing heavy or light chains, functional antibodies were assembled in the progeny. However, expression of this antibody in transgenic plants had no effect on nematode parasitism and reproduction. Expression of the antibodies and the stylet secretions in different parts of the plants could explain these results. Several other antibodies against plant pathogens have also been expressed in plants $(19,40)$ and are summarized in Table 1.

\section{ANTIBODIES AGAINST CSS IN MAIZE}

Antibody selection. Monoclonal antibodies specific to spiroplasmas and phytoplasmas are mainly used for disease diagnosis and pathogen differentiation $(27,31,32)$. From the perspective of any pragmatic application of antibodies for disease control, it would be highly desirable to obtain antibodies that are not only pathogen

TABLE 1. Expression of plant pathogen-specific antibodies and antibody fragments in plants

\begin{tabular}{|c|c|c|c|}
\hline Antibodies against & Transformed plants & Reactions upon infection & References \\
\hline Artichoke mottled crinkle virus coat protein $(\mathrm{scFv})$ & Tobacco & Reduced infection; delayed symptom development & Tavladoraki et al. (37) \\
\hline Botrytis cinerea-produced cutinase (full size) & Tobacco & Not reported & van Engelen et al. (40) \\
\hline Tobacco mosaic virus surface epitopes (full size) & Tobacco & Reduced necrotic lesion numbers & Voss et al. (41) \\
\hline Root-knot nematode stylet secretions (full size) & Tobacco & No influence on root-knot nematode infection & Baum et al. (5) \\
\hline $\begin{array}{l}\text { Beet necrotic yellow vein virus coat protein or } 25 \mathrm{kDa} \\
\text { nonstructural protein }(\mathrm{scFv})\end{array}$ & Tobacco & Not reported & Fecker et al. (19) \\
\hline Spiroplasma kunkelii membrane protein $(\mathrm{scFv})$ & Maize & No resistance & Chen and Chen (11) \\
\hline
\end{tabular}

TABLE 2. Serological tests with the selected anti-corn stunt spiroplasma (CSS) (Spiroplasma kunkelii) monoclonal antibodies

\begin{tabular}{|c|c|c|c|c|c|c|c|c|}
\hline \multirow[b]{2}{*}{ Tests } & \multicolumn{7}{|c|}{ Monoclonal antibodies against CSS } & \multirow[b]{2}{*}{ Whole cell sera ${ }^{\mathrm{a}}$} \\
\hline & $1 \mathrm{H} 1$ & $2 \mathrm{~B} 6$ & 2B11 & 2D10 & $3 \mathrm{D} 7$ & $4 \mathrm{~B} 3$ & 4B9 & \\
\hline Deformation $^{b}$ & 32 & 64 & 64 & 32 & 128 & 32 & 32 & 1 to $2 \times 10^{4}$ \\
\hline Metabolism inhibition $^{c}$ & 16 & 32 & 32 & 8 & 64 & 16 & 8 & $10^{4}$ to $10^{5}$ \\
\hline Growth inhibition ${ }^{d}$ & $\mathrm{nd}^{\mathrm{e}}$ & 3.0 & 3.0 & nd & 5.0 & nd & nd & 10 to 18 \\
\hline
\end{tabular}

a Data from Chen and Chen (10) and Whitcomb et al. (42).

b Titers expressed reciprocal of endpoint dilution of antibodies (or antisera) at which at least half of helical spiroplasma cells were deformed.

c Titers given as reciprocal of endpoint dilution of antibodies (or antisera) that inhibited spiroplasma growth.

$\mathrm{d}$ Width $(\mathrm{mm})$ of inhibition zone measured from the margin of the disk to the edge of the zone.

e nd = Not done. 
specific but also have the ability to abolish pathogenicity, biological activity, or both. Currently, very little is known about antigenic components of spiroplasmas and phytoplasmas that specify pathogenicity or biological vitality. This lack of knowledge limits the chance to produce antibodies directly against these components. Fortunately, as is the case in others of the class Mollicutes, the antisera of spiroplasmas have the ability to inhibit their growth and metabolism in vitro and deform their spiral shape (45). Therefore, it is possible to screen monoclonal antibodies with inhibitory activity against spiroplasmas. Theoretically, antibodies with similar functions against phytoplasmas should be present; however, it is difficult to prove this in vitro because of our inability to cultivate phytoplasmas. Awumbila and Rosenbusch (3) hypothesized a mechanism of antibody-mediated metabolism and growth inhibition. They proposed that antibody binding may block a specific metabolic function such as transport, enzymatic activity, or signal transduction. Alternatively, they suggested that antibody binding may decrease membrane fluidity. This binding may eventually result in inhibition of DNA replication at the molecular level and cessation of growth as proposed by Krasue and Baseman (30). In addition, agglutination of cells by antibodies could play an important role in the decrease of metabolism and viability (20).

A panel of monoclonal antibodies against CSS was produced. Those with strong inhibitory activity against CSS were further screened by using the traditional serological assays of spiroplasma identification, i.e., deformation, metabolism inhibition, and growth inhibition tests (44). In deformation tests (45), serial twofold-diluted antibody supernatant was mixed with log-phase culture of CSS cells in the wells of a microtiter plate. After $30 \mathrm{~min}$ to $1 \mathrm{~h}$ of incubation at $30^{\circ} \mathrm{C}$, samples were observed under a dark-field microscope. The titer of the deformation test was determined as the highest dilution well in which at least one half of the helical spiroplasmas were either completely or partially deformed. Metabolism inhibition tests (39) are based on the ability of antibodies to prevent or decrease the production of acidic by-products of spiroplasmas. Serial twofolddiluted antibody supernatant was cocultured with CSS cells. Final readings were made after 4 days of incubation at $30^{\circ} \mathrm{C}$. The metabolic inhibition levels were indicated by color change of the acidbase indicators in the medium. Growth inhibition tests (14) were performed using the standard disk method. A sterile concentration disk saturated with antibody supernatant was placed at the center of a agar plate with spiroplasma cells spread evenly over the surface of the culture medium. After 2 weeks of incubation at $30^{\circ} \mathrm{C}$, the inhibition zone with no or fewer spiroplasma colonies was measured under a dissecting microscope. The culture supernatant of the myeloma cell line NS-1 was used as negative control for all three tests. By using these serological methods, seven monoclonal antibodies showing good inhibitory activity were selected (Table 2). It is interesting to note that the three best monoclonal antibodies (2B6, 2B11, and 3D7) were against a protein with an apparent molecular weight of about $30 \mathrm{kDa}$. In addition, these antibodies had no cross reaction with $S$. citri, suggesting that this protein was relatively species specific for $S$. kunkelii. The specific biological function of this protein is unclear, and further investigation into the role of the antigen is necessary.

Compared with the whole cell sera (polyclonal antibodies), the selected monoclonal antibodies showed lower inhibition titers in these serological tests (Table 2). Since many different antibodies present in the serum against cell surface antigens or different epitopes of the same antigen contributed to these serological reactions (42), the results of lower readings for monoclonal antibodies in these tests were anticipated. Furthermore, although we obtained a larger number of monoclonal antibodies, we were still concerned that antibodies for some rare and less-antigenic antigens might be missed during the process of antibody screening. These antigens may have prominent roles in important biological functions or pathogenicity.

scFv construction. First-strand cDNA was synthesized from the total messenger RNA isolated from the mixture of the selected hybridoma cell lines that secreted anti-CSS antibodies. The $\mathrm{V}_{\mathrm{H}}$ and $\mathrm{V}_{\mathrm{L}}$ fragments were amplified from cDNA by PCR. The fragments were then assembled into a single gene with the pattern $\mathrm{V}_{\mathrm{H}^{-}}$ LINKER- $\mathrm{V}_{\mathrm{L}}$. These synthesized $\mathrm{scFv}$ genes were cloned into a phagemid and expressed as a fusion protein at the surface of phage M13 using the phage display system. Positive clones with CSSbinding ability were screened by enzyme-linked immunosorbent assay (ELISA). Although it is generally stated that the affinity and stability of $\mathrm{scFv}$ are comparable to their parental antibodies $(6,36)$, our scFv had more than 100 -fold lower affinity compared with the original antibodies when measured by ELISA. Similar results have been reported by other researchers $(5,9,37)$. This low affinity might be a serious drawback of $\mathrm{scFv}$ in applications requiring high affinity. It has been reported that the affinity of a $\mathrm{scFv}$ might be improved by altering the linker length or variable domain orientation $(1,17,43)$.

One of the positive scFv, E7-scFv, displayed a certain degree of inhibition against CSS when compared with the negative control. However, it was much less effective in its inhibition in the growth and metabolism tests for CSS as compared with the hybridoma-

\section{Variable Heavy chain}

\begin{tabular}{|c|c|c|c|c|c|c|c|c|c|c|}
\hline \multirow[b]{2}{*}{ A2 } & \multicolumn{2}{|c|}{ FWI } & CDRI & \multicolumn{2}{|r|}{ FW2 } & CDR2 & \multicolumn{2}{|c|}{ FW3 } & \multicolumn{2}{|c|}{ CDR3 } \\
\hline &. .30 & aa. & SYVMH & $\ldots 14$ & aa.. & YFNPYNDGTQYNEKFKG & 32 & aa. & SGLYD & YYSMDY \\
\hline B9 &. .30 & aa.. & SYVMH & $\ldots 14$ & aa.. & YINPYNDGTKYNEKFKG &. .32 & aa. & YSL & DY \\
\hline D5 &. .30 & aa & SYAMH & $\ldots 14$ & aa. & YINPYNDGTKYNEKFKG & $\ldots 32$ & aa. & YSF & DY \\
\hline F12 &. .30 & aa. & SYVMH & $\ldots 14$ & aa & YINPYNDGTKYNEKFKG & .32 & aa. & YSF & DY \\
\hline E7 &. .30 & aa. & SYGMS & $\ldots 14$ & aa. & TINSNGGSNYYPDSVKG & .32 & a. & FDGY & TYAMDY \\
\hline
\end{tabular}

\section{Variable Light Chain}

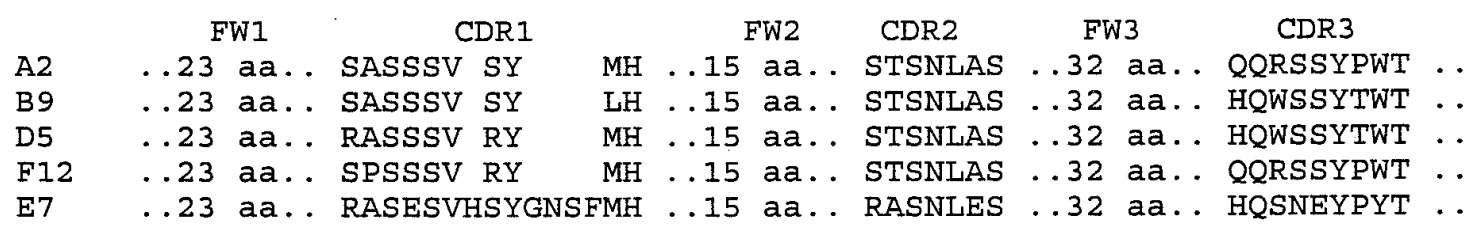

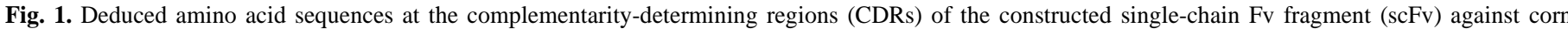

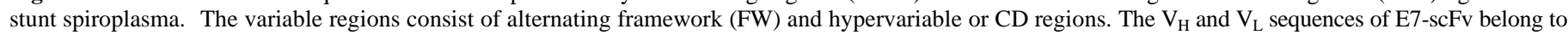

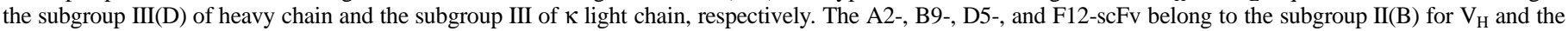
subgroup VI for $\mathrm{V}_{\mathrm{L}}$. Compared with A2-, B9-, D5-, and F12-scFv, the E7-scFv had longer CDR3 for heavy chain and CDR1 for light chain. 
derived antibodies. The scFv has only one antigen-binding site and is not able to cross-link spiroplasma cells. Since agglutination of cells by antibodies may play a role in metabolism inhibition and viability (20), the lack of agglutination ability may explain why single-chain antibodies are less effective in inhibition tests compared with those of hybridoma-derived antibodies. If this hypotheses is true, expression of full-size antibodies in plants may be a better choice for controlling spiroplasma and phytoplasma diseases.

By comparing the sequences of E7-scFv and the other four $\mathrm{scFv}$ with the Kabat database (28), we found that the $\mathrm{V}_{\mathrm{H}}$ and $\mathrm{V}_{\mathrm{L}}$ sequences of E7-scFv belonged to the subgroup III(D) of heavy chain and the subgroup III of $\kappa$ light chain, respectively. The other four $\mathrm{scFv}$ antibodies belonged to $\mathrm{II}(\mathrm{B})$ for $\mathrm{V}_{\mathrm{H}}$ and $\mathrm{VI}$ for $\mathrm{V}_{\mathrm{L}}$. In addition, E7-scFv had longer CDRs (Fig. 1). We do not know, however, whether or not these differences make E7-scFv superior to others in inhibition tests.

We have also attempted to construct $\mathrm{scFv}$ against a New Jersey strain of the aster yellows phytoplasma, but without success. This could be due to the low affinity of $\mathrm{scFv}$ that were unable to show a positive reaction to the low titer of phytoplasma in ELISA screening. Another possible reason is that functional $\mathrm{scFv}$ cannot be made from the monoclonal antibody we used.

Expression of scFv in maize. The $\mathrm{E} 7-\mathrm{scFv}$ gene was cloned into a plant expression vector under the control of the maize ubiquitin gene 1 (Ubi-1) promoter with the bar gene encoding resistance to the herbicide as a selective marker (12). The Ubi-1 promoter has been reported to increase gene expression in monocots (including maize) from 2.5- to 50-fold compared with the cauliflower mosaic virus $35 \mathrm{~S}$ promoter in a similar construction $(12,38)$. Our gene construct was designed to allow constitutive expression of $\mathrm{scFv}$ in the cytoplasm. The gene construct was delivered into maize cells by particle bombardment (29) using a PDS-1000/He Biolistic Delivery System (Bio-Rad Laboratories, Hercules, CA). One cell line, designated as E7-1, was genetically confirmed as being transformed. ELISA analysis revealed that scFv expressed in this cell line and in the regenerated plants exhibited CSS-binding activity. Plants regenerated from this cell line were challenged with $S$. kunkelii using infective corn leafhoppers (Dalbulus maidis) as a vector. Unfortunately, the transgenic plants did not exhibit resistance to CSS infection.

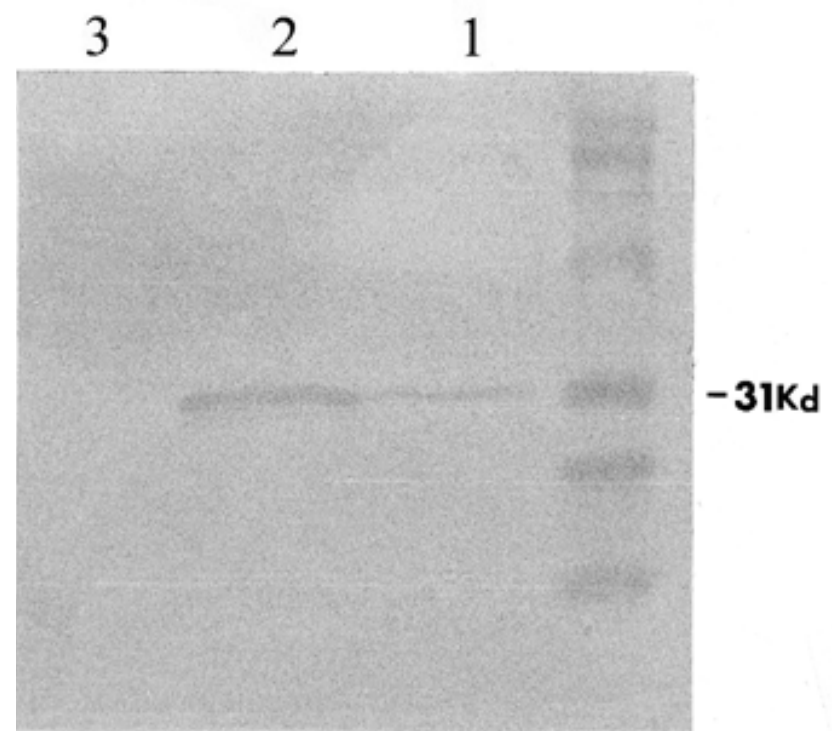

Fig. 2. Western blot analysis of the expressed E7-single-chain Fv fragment $(\mathrm{scFv})$ in maize. Total proteins isolated from control plant, transformed maize cells, and the regenerated transgenic plant were run on a sodium dodecyl sulfate polyacrylamide gel electrophoresis gel, blotted onto the membrane and then detected by anti-E-tag antibody (the E-tag was fused at the $3^{\prime}$ end of E7-scFv). Sixty micrograms of total proteins was loaded per each lane. Lane 1, control plant. Lane 2, transformed maize callus. Lane 3, regenerated transgenic plant.
Since only one cell line was studied, it is difficult to form a plausible explanation for these results. One reason could be due to the $\mathrm{scFv}$ itself. The $\mathrm{scFv}$ was much less effective in inhibiting the growth and metabolism of CSS than was the hybridoma-derived antibody. The expression site of scFv in maize plant could be another factor. CSSs are restricted in the phloem sieve tubes. It is unknown whether enough $\mathrm{scFv}$ expressed in the cytoplasm of companion cells was effectively transferred into mature sieve tubes to be useful against CSS. Baum et al. (5) reported that a functional monoclonal antibody specific to stylet secretions of the root-knot nematode in tobacco had no influence on nematode parasitism. The authors proposed that nematode stylet secretions might have been injected into the cytoplasm, and the expressed antibody probably accumulated in ER and apoplastic spaces. A similar situation may have affected our results. It might be a better choice to put the $\mathrm{scFv}$ gene under the control of a phloem-specific promoters $(35,46)$. In addition, the amount of scFv antibody in the plant may be too low to affect CSS growth. We observed that the scFv expression level in regenerated plant tissue was much lower than that in callus (Fig. 2). Schouten et al. (34) reported that an endoplasmic reticulum retention signal sequence KDEL at the C-terminal greatly increases the expression levels of $\mathrm{scFv}$ in tobacco plants; this sequence may also work in maize.

\section{CONCLUSIONS}

The anti-CSS ScFv gene we constructed has been used to transform corn plants. $\mathrm{scFv}$ was expressed in the transformed callus cells and in regenerated corn plants, but the antibodies were not able to confer CSS resistance. Even though the results did not meet our proposed objective, we should not rule out that the scFv gene is not suitable for developing transgenic maize plants with resistance to CSS infection, as more transgenic cell lines need to be tested. Currently, we are also attempting to express full-size antibodies against CSS in plants. Only by further experimentation can we explain the inability of $\mathrm{scFv}$ to stop CSS infection in transgenic maize plants.

\section{ACKNOWLEDGMENTS}

This work was supported, in part, by the New Jersey Agriculture Experiment Station. We thank M. Bergen for critical reading of the manuscript.

\section{LITERATURE CITED}

1. Anand, N. N., Mandal, S., MacKenzie, C. R., Sadowska, J., Sigurskjold, B., Young, N. M., Bundle, D. R., and Narang, S. A. 1991. Bacterial expression and secretion of various single-chain $\mathrm{Fv}$ genes encoding proteins specific for a Salmonella serotype B O-antigen. J. Biol. Chem. 266:21874-21879.

2. Artsaenko, O., Peisker, M., zur Nieden, U., Fiedler, U., Weiler, E. W., Müntz, K., and Conrad, U. 1995. Expression of a single-chain Fv antibody against abscisic acid creates a wilty phenotype in transgenic tobacco. Plant J. 8:745-750.

3. Awumbila, B., and Rosenbusch, R. F. 1991. Metabolism inhibition as a result of interaction of antibody with a membrane protein of Mycoplasma bovoculi. Curr. Microbiol. 22:221-224.

4. Barton, K. A., Binns, A. N., Matzke, A. J. M., and Chilton, M.-D. 1983. Regeneration of intact tobacco plants containing full length copies of genetically engineered T-DNA and transformation of T-DNA to R1 progeny. Cell 32:1033-1043.

5. Baum, T. J., Hiatt, A., Parrott, W. A., Pratt, L. H., and Hussey, R. S. 1996. Expression in tobacco of a functional monoclonal antibody specific to stylet secretions of the root-knot nematode. Mol. Plant-Microbe Interact. 9:382-387.

6. Bird, R. E., Hardman, K. D., Jacobson, J. W., Johnson, S., Kaufman, B. M., Lee, S.-M., Lee, T., Pope, S. H., Riordan, G. S., and Whitlow, M. 1988. Single-chain antigen-binding protein. Science 242:423-426.

7. Boulianne, G. L., Hozumi, N., and Shulman, M. J. 1984. Production of functional chimaeric mouse/human antibody. Nature 312:643-646.

8. Brinkmann, U., and Pastan, I. 1995. Recombinant immunotoxins: From basic research to cancer therapy. Methods: A Companion to Methods in Enzymology 8:143-156. 
9. Bruyns, A.-M., De Jaeger, G., De Neve, M., De Wilde, C., Van Montagu, M., and Depicker, A. 1996. Bacterial and plant-produced scFv proteins have similar antigen-binding properties. FEBS (Fed. Eur. Biochem. Soc.) Lett. 386:5-10.

10. Chen, C. S., and Chen, T. A. 1980. Comparison of immunized mouse ascites fluids and rabbit sera in serological tests of two spiroplasmas. Phytopathology 70:279-282.

11. Chen, Y. D., and Chen, T. A. 1996. Expression of anti corn stunt Spiroplasma single chain antibody fragments in maize plants. (Abstr.) Phytopathology 86:S95.

12. Christensen, A. H., Sharrock, R. A., and Quail, P. H. 1992. Maize polyubiquitin genes: Structure, thermal perturbation of expression and transcript splicing, and promotor activity following transfer to protoplasts by electroporation. Plant Mol. Biol. 18:675-689.

13. Clackson, T., Hoogenboom, H. R., Griffith, A. D., and Winter, G. 1991. Making antibody fragments using phage display libraries. Nature 352: 624-628.

14. Clyde, Jr., W. A. 1964. Mycoplasma species identification based upon growth inhibition by specific antisera. J. Immunol. 92:958-965.

15. Conrad, U., and Fiedler, U. 1994. Expression of engineered antibodies in plant cells. Plant Mol. Biol. 26:1023-1030.

16. De Neve, M., De Loose, M., Jacobs, A., Van Houdt, H., Kaluza, B., Weidle, U., Van Montagu, M., and Depicker, A. 1993. Assembly of an antibody and its derived antibody fragment in Nicotiana and Arabidopsis. Transgen. Res. 2:227-237.

17. Desplancq, D., King, D. J., Lawson, A. D. G., and Mountain, A. 1994. Multimerization behaviour of single chain Fv variants for the tumourbinding antibody B72.3. Protein Eng. 7:1027-1033.

18. Düring, K., Hippe, S., Kreuzaler, F., and Schell, J. 1990. Synthesis and self-assembly of a functional monoclonal antibody in transgenic Nicotiana tabacum. Plant Mol. Biol. 15:281-293.

19. Fecker, L. F., Kaufmann, A., Commandeur, U., Commandeur, J., Koenig, R., and Burgermeister, W. 1996. Expression of single-chain antibody fragments ( $\mathrm{scFv}$ ) specific for beet necrotic yellow vein virus coat protein or $25 \mathrm{Kda}$ protein in Escherichia coli and Nicotiana benthamiana. Plant Mol. Biol. 32:979-986.

20. Feldmann, R.-C., Henrich, B., Kolb-Bachofen, V., and Hadding, U. 1992. Decreased metabolism and viability of Mycoplasma homonis induced by monoclonal antibody-mediated agglutination. Infect. Immun. 60:166-174.

21. Firek, S., Draper, J., Owen, M. R. L., Gandecha, A., Cockburn, B., and Whitelam, G. C. 1993. Secretion of a functional single-chain Fv protein in transgenic tobacco plants and cell suspension cultures. Plant Mol. Biol. 23:861-870.

22. Hiatt, A., Cafferkey, R., and Bowdish, K. 1989. Production of antibodies in transgenic plants. Nature 342:76-78.

23. Hiatt, A., and Mostov, K. 1993. Assembly of multimeric proteins in plant cells: Characteristics and uses of plant-derived antibodies. Pages 221-237 in: Transgenic Plants: Fundamentals and Applications. A. Hiatt, ed. Marcel Dekker, Inc., New York.

24. Huijsman-Evers, A. G. M., and Ruys, A. C. 1956. Microorganisms of the pleuropneumonia group (family of Mycoplasmataceae) in man. II. Serological identification and discussion of pathogenicity. Antonie Leeuwenhoek 22:377-384.

25. Huston, J. S., Levinson, D., Mudgett-Hunter, M., Tai, M.-S., Novotny, J., Margolies, M. N., Ridge, R. J., Bruccoleri, R. E., Haber, E., Crea, R., and Oppermann, H. 1988. Protein engineering of antibody binding sites: Recovery of specific activity in an anti-digoxin single-chain Fv analogue produced in Escherichia coli. Proc. Natl. Acad. Sci. U.S.A. 85:5879-5883.

26. Jones, P. T., Dear, P. H., Foote, J., Neuberger, M., and Winter, G. 1986. Replacing the complementarity-determining regions in a human antibody with those from a mouse. Nature 321:522-525.

27. Jordan, R. L., Konai, M., Lee, I.-M., and Davis, R. E. 1989. Species-specific and cross-reactive monoclonal antibodies to the plant-pathogenic spiroplasmas Spiroplasma citri and S. kunkelii. Phytopathology 79:880-887.
28. Kabat, E. A., Wu, T. T., Reid-Miller, M., Perry, H. M., and Gottesman, K. S. 1991. Sequences of proteins of immunological interest. 5th ed. U.S. Department of Health and Human Services, National Institutes of Health, Washington, DC.

29. Klein, T. M., Wolf, E. D., Wu, R., and Sanford, J. C. 1987. High velocity microprojectiles for delivering nucleic acids into living cells. Nature 327:70-73.

30. Krause, D. C., and Baseman, J. B. 1983. Inhibition of Mycoplasma pneumoniae hemadsorption and adherence to respiratory epithelium by antibodies to a membrane protein. Infect. Immun. 39:1180-1186.

31. Lin, C. P., and Chen, T. A. 1985. Monoclonal antibodies against the aster yellows agent. Science 227:1233-1235.

32. Lin, C. P., and Chen, T. A. 1985. Production of monoclonal antibodies against Spiroplasma citri. Phytopathology 75:848-851.

33. Owen, M., Gandecha, A., Cockburn, B., and Whitelam, G. 1992. Synthesis of a functional anti-phytochrome single-chain Fv protein in transgenic tobacco. Biotechnology 10:790-794.

34. Schouten, A., Roosien, J., van Engelen, F. A., (Ineke) de Jong, G. A. M. (Tanja) Borst-Vrenssen, A. W. M., Zilverentant, J. F., Bosch, D., Stikema, W. J., Gommers, F. J., Schots, A., and Bakker, J. 1996. The Cterminal KDEL sequence increases the expression level of a single-chain antibody designed to be targeted to both the cytosol and the secretory pathway in transgenic tobacco. Plant Mol. Biol. 30:781-793.

35. Shi, Y., Wang, M. B., Powell, K. S., Van Damme, E., Hilder, V. A., Gatehouse, A. M. R., Boulter, D., and Gatehouse, J. A. 1994. Use of the rice synthase-1 promoter to direct phloem-specific expression of glucuronidase and snowdrop lectin genes in transgenic tobacco plants. J. Exp. Bot. 45:623-631.

36. Takkinen, K., Laukkanen, M.-L., Sizmann, D., Alfthan, K., Immonen, T., Vanne, L., Kaartinen, M., Knowles, J. K. C., and Teeri, T. T. 1991. An active single-chain antibody containing a cellulase linker domain is secreted by Escherichia coli. Protein Eng. 4:837-841.

37. Tavladoraki, P., Benvenuto, E., Trinca, S., Martinis, D. D., Cattaneo, A., and Galeffi, P. 1993. Transgenic plants expressing a functional single-chain Fv antibody are specifically protected from virus attack. Nature 366:469-472.

38. Taylor, M. G., Vasil, V., and Vasil, I. K. 1993. Enhanced GUS gene expression in cereal/grass suspensions and immature embryos using the maize ubiquitin-based plasmid pAHC25. Plant Cell Rep. 2:491-495.

39. Taylor-Robinson, D., Purcell, R. H., Wong, D. C., and Chanock, R. M. 1966. A colour test for the measurement of antibody to certain mycoplasma species based upon the inhibition of acid production. J. Hyg. (Cambridge) 64:91-104.

40. Van Engelen, F. A., Schouten, A., Molthoff, J. W., Roosien, J., Salinas, J., Dirkse, W. G., Schots, A., Bakker, J., Gommers, F. J., Jongsma, M. A., Bosch, D., and Stiekema, W. J. 1994. Coordinate expression of antibody subunit genes yields high levels of functional antibodies in roots of transgenic tobacco. Plant Mol. Biol. 26:1701-1710.

41. Voss, A., Niersbach, M., Hain, R., Hirsch, H. J., Liao, Y. C., Kreuzaler, F., and Fischer, R. 1995. Reduced virus infectivity in N. tabacum secreting a TMV-specific full-size antibody. Mol. Breed. 1:39-50.

42. Whitcomb, R. F., Tully, J. G., and Wróblewski, H. 1983. Spiralin: Major membrane protein specific for subgroup I-1 spiroplasmas. Curr. Microbiol. 9:7-12.

43. Whitlow, M., Bell, B. A., Feng, S.-L., Filpula, D., Hardman, K. D., Hubert, S. L., Rollence, M. L., Wood, J. F., Schott, M. E., Milenic, D. E., Yokota, T., and Schlom, J. 1993. An improved linker for single-chain Fv with reduced aggregation and enhanced proteolytic stability. Protein Eng. 6:989-995.

44. Williamson, D. L., and Whitcomb, R. F. 1983. Special serological tests for spiroplasma identification. Pages 249-259 in: Methods in Mycoplasmology, Vol. II, Diagnostic Mycoplasmology. J. G. Tully and S. Razin, eds. Academic Press, New York.

45. Williamson, D. L., Whitcomb, R. F., and Tulley, J. G. 1978. The spiroplasma deformation test, a new serological method. Curr. Microbiol. 1:202-207.

46. Yang, N.-S., and Russell, D. 1990. Maize sucrose synthase-1 promoter directs phloem cell-specific expression of Gus gene in transgenic tobacco plants. Proc. Natl. Acad. Sci. U.S.A. 87:4144-4148. 